\title{
MATERIALIDADE DOS MITOS INDÍGENAS NARRADOS NOS SÉCULOS XVI E XVII E SUAS RELAÇÕES ICONOGRÁFICAS COM AS PINTURAS RUPESTRES DA TRADIÇÃO NORDESTE, BRASIL
}

¿Museu de Arqueologia e Etnologia USP.

mariliaperazzo@usp.br

ii Departamento de Arqueologia da Universidade Federal de

Pernambuco - UFPE.

danielacisneiros@yahoo.com.br

iii Departamento de Arqueologia da Universidade Federal de Pernambuco - UFPE.

cccrios@hotmail.com

\author{
Marília Perazzo ${ }^{i}$ \\ Daniela Cisneiros ${ }^{\mathrm{ii}}$ \\ Carlos Rios iii
}

Resumo: O objetivo central deste artigo foi buscar estabelecer homologias entre os componentes materiais inseridos nas cenas de conteúdo mítico das narrativas quinhentistas e seiscentistas e os existentes nas pinturas rupestres de Tradição Nordeste do Brasil. 0 mito retratado nos relatos quinhentistas foi analisado em uma perspectiva historiográfica a partir de cinco parâmetros: Tema, Tempo, Espaço, Dinâmica e Componentes da narrativa. As pinturas rupestres foram analisadas a partir das dimensões temáticas e cenográficas. Os estudos das fontes históricas e arqueológicas, por meio da análise da dimensão material e gestual, permitiu constatar a presença de estruturas homólogas entre alguns componentes de tais narrativas imbuídas de aspectos míticos, tendo como principais elementos a árvore, o pássaro profético e o maracá.
\end{abstract}

Palavras-Chave: Mitos indígenas; Homologias; Pinturas Rupestres.

Abstract: The central objective of this article was to establish homologies among the material components inserted in the mythical content scenes of the 16th and 17th century narratives and those existing in the rock art of the Nordeste Tradition of Brazil. The myth depicted in the fifteenth-century accounts was analyzed in a historiography perspective from five parameters: Theme, Time, Space, Dynamics and Components of the narrative, while in the rock art the thematic and scenographic dimensions were analyzed. The study of historical and archaeological sources, through the analysis of the material and gestural dimensions, allowed us to verify the presence of homologous structures between some components of such narratives imbued with mythical aspects, having as main elements the tree, the prophetic bird and the maraca.

Keywords: Indigenous myths; Homologies; Rock art. 


\section{Introdução}

Nos povos de tradição oral, as inquietações existenciais e sagradas constituem a matéria-prima principal do que se designa como mito (Eliade, 2001). Os mitos experimentam transformações através do tempo, influenciados pelos acontecimentos das histórias dos povos. 0 processo de mutação sofrido pelo discurso, com o passar do tempo, afeta diretamente a dinâmica dos acontecimentos em uma relação de constante interação. Assim, a narrativa mítica se metamorfoseia e múltiplos significados são evocados na busca de sua dimensão ontológica.

A multiplicidade de leituras e as construções sobre o mito se manifestam de formas diferentes na dimensão material dos ritos vinculados a estes mitos. Os ritos possuem uma função de marcador de memória, sobretudo para os povos de tradição oral, pode-se dizer que contém sua memória gestual. O conhecimento material e gestual do rito é necessário para a perpetuação da tradição cultural dos grupos (Eliade, 2000).

Os mitos dos indígenas pertencentes ao tronco linguístico Tupi, presentes nos relatos quinhentistas e seiscentistas, bem como os componentes rituais existentes nas cenas narrativas das pinturas rupestres abordam temas que eram correntes no cotidiano dos povos autores. Tais temáticas, muitas vezes imbuídas de teor alegórico, eram inseridas nas explicações sobre as principais preocupações dos povos de tradição oral para elucidar o desconhecido.

O objetivo desse artigo é discutir e apresentar a dimensão material dos mitos conservados pela tradição oral, levantada a partir das narrativas e das iconografias do século XVI/XVII e buscar homologias com os grafismos reconhecíveis pela sua dinâmica gráfica-narrativa, classificados como Tradição Nordeste. Observando os elementos da gestualidade aliados aos componentes materiais das narrativas, pode-se confrontar tais mitos às temáticas das pinturas rupestres.

Para essa pesquisa, foram utilizadas as obras de autores que conviveram com os grupos indígenas e retrataram sua materialidade e cosmovisão, entre eles: Claude D’Abbeville, [1614] 1975; Simão de Vasconcelos, [1663] 1977; Jean de Léry, [1578] 1980; André Thevet, [1557] 1978 e Hans Staden, [1557] 1988.

Partindo-se da análise da conjuntura na qual estavam inseridos esses cronistas, é necessário antes discorrer sobre a utilização dessas fontes no contexto narrativo da materialidade. Os 
elementos ritualísticos presentes, tanto nas imagens como no corpo do texto, foram analisados do ponto de vista da materialidade, não adentrando no campo das interpretações. O estudo dessa materialidade levou ao estabelecimento de especificidades entre os componentes da narrativa. Algumas em termos da essência dos mitos e outros apenas contextuais, fornecendo informações sobre a vida cotidiana das comunidades descritas.

A assertiva dos cronistas possui elementos que, a partir da análise da materialidade, podem fornecer informações referentes à identidade, relações sociais e tecnologias. Decompor os elementos da gestualidade dos mitos narrados, observando a temática e a cenografia, bem como confrontá-la com as temáticas narrativas das pinturas rupestres, pode permitir segregar relações de cunho social e simbólico.

A exemplo de tal afirmativa, pode-se observar em algumas narrativas e imagens quinhentistas e seiscentistas, sobretudo nas iconografias de Jean De Léry, ([1578] 1980), André Thevet, ([1557] 1978) e Hans Staden ([1557] 1988), a presença de adornos em alguns componentes do grupo, em detrimento de outros. A mecânica gestual da cenografia da ação narrada e à proporção que os elementos antropomórficos aparecem na composição da cena, diferencia-os socialmente ou ritualisticamente dos demais que não aparecem igualmente adornados e em proporções diferenciadas (Figura 1).

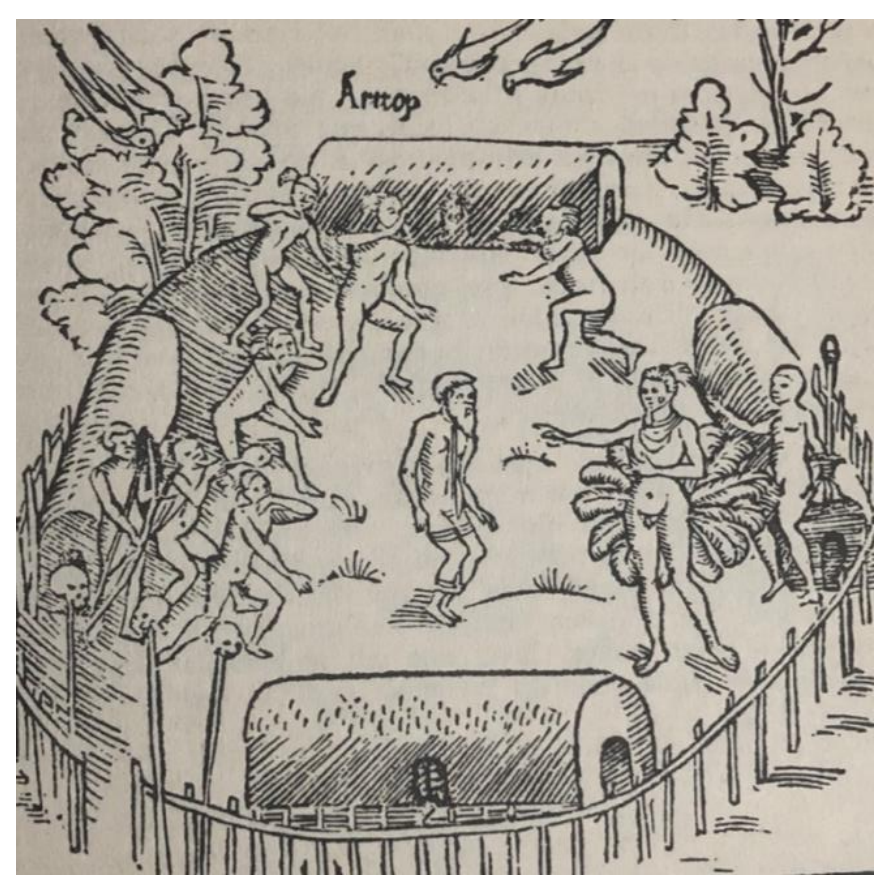

Figura 1: Imagem representada por Hans Staden, da Aldeia de Ariró, do chefe Cunhambebe, onde Staden se encontra com o chefe indígena adornado de plumas e tembetá. Fonte: Staden, H. [1557] 1988. 
A Figura 2, aqui vista como uma cena sincrônica, composta por antropomorfos enfileirados, é outro exemplo de tais distinções. No conjunto cenográfico existem duas maneiras distintas de retratar os antropomorfos. Uma com adornos e alongamento corporal que sugere indumentárias, cuja mecânica gestual aliada à ornamentação dessas figuras, e outra sem ornamentos e em composição gestual e rítmica, com membros superiores voltados para cima e membros inferiores flexionados, sugerindo reverência, mesmo que simbólica, dentre os demais componentes.

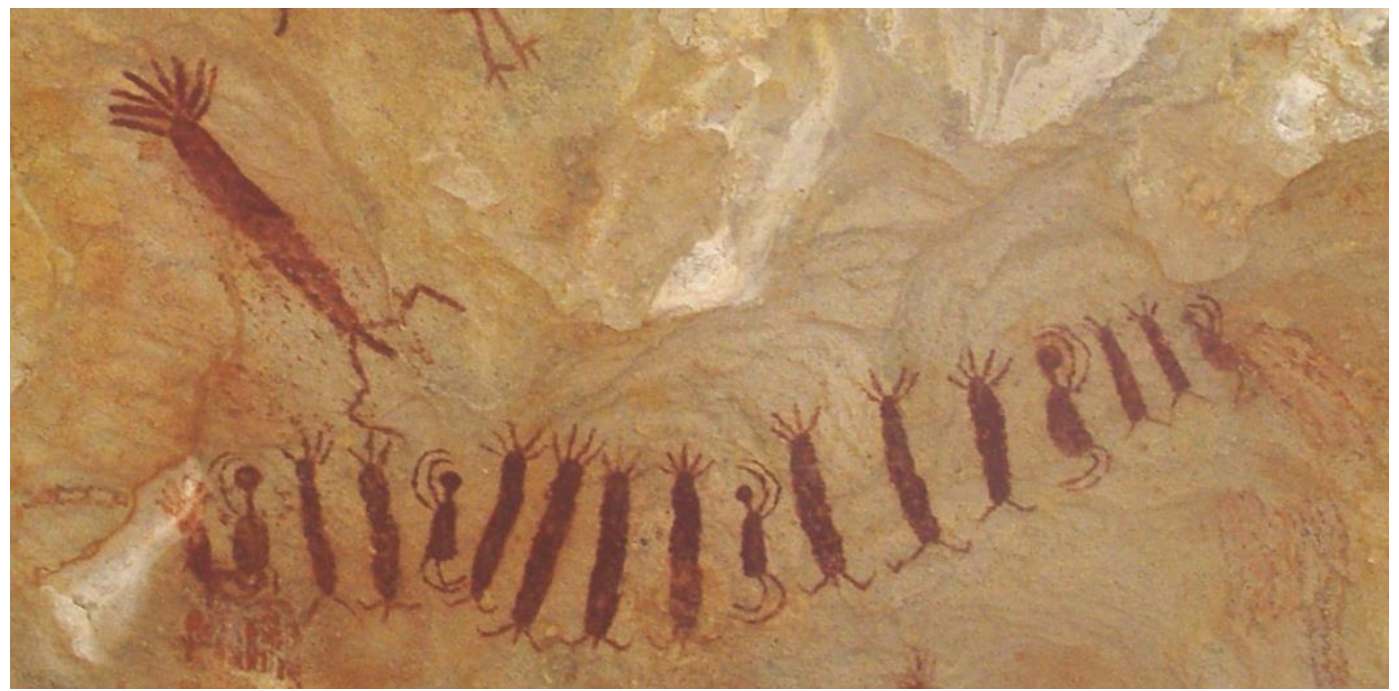

Figura 2: Antropomorfos enfileirados em atividade ritual. Toca do Baixão da Vaca. Parque Nacional Serra da Capivara - PI. Fonte: Acervo Fumdham, 2017.

As pinturas rupestres são, em sua essência, sistemas de comunicação social possuindo a função de marcadores de memória para os povos de tradição oral (Pessis, 2003). Dentro do panorama inicial dos estudos sobre registros rupestres no Brasil, Guidon (1975) propôs um ordenamento preliminar das características gerais desses registros para a região. A proposta, pautava-se na constatação de que os grupos autores imprimiam sobre a rocha particularidades gráficas próprias de sua cultura. Partindo dessa premissa, grafismos diferentes poderiam pertencer a horizontes culturais também diferentes.

O critério utilizado referia-se ao reconhecimento cognitivo dos grafismos. Alguns permitiam conhecer elementos do mundo sensível, enquanto outros eram sinais gráficos sem possibilidade de reconhecimento (Pessis, 1992). Dentro das figuras reconhecíveis foram identificadas duas classes de pinturas, denominadas Tradição ${ }^{1}$ Agreste e Tradição Nordeste: a

\footnotetext{
${ }^{1} \mathrm{O}$ conceito de Tradição é atribuído à classes ordenadas, agrupadas a partir das seleção de elementos ou técnicas similares com certa persistência temporal, que caracterizam um conjunto de vestígios arqueológicos. Essas classes podem ser associadas através de seus atributos e contextos à distintos grupos culturais (Cisneiros, D, et al. 2020)
} 
primeira, caracterizada por figuras de antropomorfos e zoomorfos em posição estática, sem o desenvolvimento de ação, e a segunda, caracterizada por figuras de antropomorfos e zoomorfos desenvolvendo ações (Cisneiros, 2008; Amaral, 2014).

Os registros rupestres categorizados como Tradição Nordeste têm como características principais a predominância de variedades de temas (antropomorfos, zoomorfos e fitomorfos), apresentam geralmente traços elaborados, contendo elementos culturais entre eles, adornos e objetos que acompanham as figuras humanas. Essa classe se caracteriza por figurações naturalistas e dinâmicas envolvidas em cenas cotidianas (dança, guerra, sexo) que são habilmente representadas, utilizando técnicas de traços leves e seguros (Martin, 2008; Pessis, 1987; 1992; Cisneiros et al, 2020).

As unidades gráficas, assim como os mitos, podem ser decompostas em unidades temáticas e materiais². A Temática está aliada ao reconhecimento da identidade do elemento, já a Material baseia-se no significante gráfico, na observação de elementos que compõem a cena.

Nesse sentido, buscar e identificar contextos de similaridade e diferenças nas pinturas rupestres permite ao pesquisador apresentar novas perspectivas e discuti-las, a luz de novos dados. Na Pré-História, as discursões sobre a busca pelo códigos é uma constante. No entanto, faz-se necessária a análise dos vestígios materiais, a partir de uma metodologia analítica que confira ao pesquisador a possibilidade de integrá-los ao contexto no qual estão inseridos e problematizar sua funcionalidade enquanto conjunto e não como fato isolado.

\section{Método}

Utilizar como fontes de pesquisa os registros históricos deixados pelos cronistas dos séculos XVI/XVII já é uma prática defendida, inclusive por Estevão Pinto (1938) em sua obra Os Indígenas do Nordeste, por serem estes importantes contribuições historiográficas para o entendimento dos modos de vida dos povos do Novo Mundo (Pinto, 1938). Tais escritores transmitiam e historicizavam suas experiências ao lado dos grupos indígenas, quando da sua vivência junto a tais populações.

\footnotetext{
2 Em função das consecutivas esferas de representação e por ser permeado por um teor alegórico, também se pode decompor o mito em unidades temáticas e materiais, quando da observação dos gestos e ornamentações atribuídas a determinados componentes, os diferenciando dos demais contidos na narrativa, ou cena pintada (Leite, 2000).
} 
Quanto à independência das fontes, Florestan Fernandes (1975) se refere à influência dos autores, não só segundo as instituições religiosas e políticas das quais são pertencentes, mas também ressalta a literatura por eles consultada (Cisneiros, 2003).

A postura de Fernandes em alegar que as obras de cronistas e viajantes podem ser consideradas, observando a independência e autoridade, gerou críticas severas entre historiadores e etnólogos, como Raminelli (1994) e Oliveira Filho (1987).

\begin{abstract}
A análise da documentação quinhentista e seiscentista dedicada ao cotidiano indígena permite ainda repensar as pesquisas etnográficas sobre os antigos Tupinambás. Alfred Metraux, Florestan Fernandes e Eduardo Viveiro de Castro, entre tantos outros tupinólogos, leram os relatos deixados por europeus, como homens do século XX, completamente alheios aos princípios da colonização. Hans Staden, Gabriel Soares de Sousa e Jean de Léry não eram etnógrafos (....). Para os antropólogos, as narrativas sobre ritos e mitos escritas pelos primeiros exploradores tornam-se confiáveis quando encontram similitudes com as etnografias atuais, ou quando foram descritas por mais de um testemunho. Para os historiadores os critérios apresentados pelos tupinólogos, são frágeis, pois um mesmo evento pode expressar um determinado significado no século XVI e outro, tempos depois (Raminelli, 1994, p. 257-8).
\end{abstract}

A crítica de Raminelli (1994) à analogia é justa, mas a preocupação etnológica atual proclama que cada geração lê as grandes obras dessa literatura produzida por cronistas e viajantes de maneira diferente e distintiva, de acordo com o seu universo simbólico. Um dos principais indícios valorativos dessas obras encontra-se exatamente na riqueza intrínseca de suas descrições (Cisneiros, 2003).

Nesse sentido, faz-se necessário, porém, que o historiador ou o arqueólogo se conscientize que toda a informação positiva fornecida por um cronista se refere ao particular modo de observar àquele grupo pelos autores, àquela época. Utilizando as palavras de Oliveira Filho:

O valor etnográfico de um relato histórico não é em si maior ou menor que dados de observação direta; seu valor é instrumental e depende da definição do conteúdo da investigação realizada (Oliveira Filho, 1987, p. 89).

De certo, as narrativas de cronistas e viajantes reservam as particularidades de uma época histórica, como descrito por Lévi-Strauss (1993) em Tristes Trópicos, os antigos viajantes, confrontado com um prodigioso espetáculo, do qual tudo ou quase tudo the escapava, são condicionados à paixão, à loucura e aos equívocos de viagens. Seguindo essas argumentações é necessário ponderar esses dados, filtrando os elementos materiais e sobretudo as descrições técnicas. 
Assim, ao abordar tais fontes históricas, deve-se considerar a perspectiva ideológica desses autores para poder ponderar as informações. Localizá-los no tempo e no espaço se faz de grande importância, pois as diferentes missões que estiveram no Brasil, tinham concepções e formas diferenciadas de lidar com os indígenas. Saber a procedência, a época em que no Brasil estiveram, dá margem para um entendimento mais amplo do ponto de vista contextual (Amaral, 2008).

Alguns cronistas como, por exemplo, Hans Staden ([1557] 1988), narram suas experiências de cativeiros no seio das comunidades Tupi-guarani. Em suas descrições, a dimensão subjetiva, consequência de tal experiência, se manifesta em uma série de juízos de valor. No entanto, os componentes materiais dessas fontes, são em menor proporção atingidos pela subjetividade do observador.

Nesse sentido, buscou-se estabelecer homologias entre os componentes materiais inseridos nas cenas de conteúdo mítico das narrativas e os existentes nas pinturas rupestres de Tradição Nordeste. Foi analisada apenas a estrutura, ou seja, o significante gráfico de tais componentes e não sua funcionalidade dentro do contexto narrativo. A partir das análises narrativas, buscou-se correspondências iconográficas nas temáticas rupestres, associadas à morfologia, gestualidade e postura.

O mito retratado nos relatos quinhentistas e seiscentistas foi analisado a partir de cinco parâmetros: Tema, Tempo, Espaço, Dinâmica e Componentes da narrativa. Localizou-se no tempo e no espaço o autor do relato, quais as áreas de sua visitação e sobre qual etnia se referiu. Após essa verificação prévia, iniciou-se a análise dos componentes materiais do mito, buscando-se para esse trabalho selecionar grafismos rupestres da Tradição Nordeste que apresentavam cenas na Áreas Arqueológicas Serra da Capivara - PI.

Os procedimentos de análise dos componentes rituais observados nas cenas narrativas das pinturas rupestres são alicerçados em duas variáveis: Temática e Cenografia.

A Temática é uma dimensão de fundamental importância para o desenvolvimento do trabalho, pois permite identificar, através do reconhecimento e identificação dos componentes, a sua identidade. A variável cenográfica estuda a maneira como os componentes de uma ação são agenciados. Por meio do contexto cenográfico aliado à temática dos grafismos, analisou-se, observando a série de ações articuladas, o grau de complexidade narrativa das cenas e os valores inseridos no processo narrativo. 
Os cronistas retrataram a sacralidade de povos nativos. Esses elementos estão descritos sob as diretrizes dos conceitos, dogmas e paradigmas exógenos aos grupos retratados, como já mencionados. Nos relatos verificou-se a presença recorrente de três temáticas na configuração do universo mítico dos grupos retratados: os pássaros, os maracás e as árvores, que marcaram de forma contundente a contextualização da cosmogonia dos povos nativos nessas obras.

Alguns mitos indígenas possuíam elementos materiais homólogos aos representados no corpus gráfico das pinturas rupestres. Estas figuras pertenciam à vida cotidiana das sociedades que as reproduziam graficamente ou discursivamente. Foi a partir da materialidade salientada nas duas narrativas de conteúdo mítico que se deu início às análises, verificando quais temáticas estavam associadas a cada estrutura material, gestual, postural e rítmica nas pinturas e nos textos quinhentistas e seiscentistas.

\section{A Dimensão Material dos Mitos}

\section{Os Pássaros proféticos}

O pássaro constitui um símbolo mítico, observado em distintos grupos culturais, podendo designar as relações entre o céu e a terra, pois ficam na intercessão desses dois ambientes, cabendo a eles, por muitas vezes, a representatividade divina em mitos. Por possuírem asas e voarem, esses seres elevam-se diante do mundo terreno, cujas asas terminam simbolicamente por representar os seres divinizados.

A partir dos relatos dos cronistas $\mathrm{XVI} / \mathrm{XVII}$, sobre os Tupinambá, pode-se observar narrativas em torno de divindades em forma de pássaros, representados como veículo de comunicação entre seus ancestrais. Ao abordar a variedade de aves que existiam na América do Sul, Jean de Léry ([1578] 1980), em sua obra Viagem à Terra do Brasil, descreve a crença dos Tupinambá nos pássaros proféticos, particularizando a reverência desses em relação à coruja. Para esses grupos, os ancestrais se comunicavam com eles através do canto de tais animais.

Os nossos Tupinambás imaginam, entretanto ao ouvirem-na clamarem à noite, principalmente, serem seus parentes e amigos mortos que a enviam em sinal de boa fortuna, para animá-los na guerra; creem firmemente que observando o que lhe indica o augúrio não só vencerão os inimigos dessa terra, mas ainda, depois da morte, o que é mais importante, irão dançar com seus ancestrais além das montanhas. 
Certa noite em que dormi numa aldeia chamada Ypec pelos franceses, ouvi à tarde cantarem esses pássaros um canto melancólico e vi os selvagens que darem silenciosos e atentos. Conhecendo a causa de tal atitude, quis convencê-los de seu erro. Mas apenas toquei no assunto e me pus a rir juntamente com outro francês que me acompanhava, um ancião ali presente exclamou com rudeza: "Cala-te e não nos impeça de ouvir as boas novas que nos enviam nossos avós; quando ouvimos essas aves ficamos todos contentes e nos sentimos com novas forças (Jean de Léry, [1578] $1980 ; 153-154)$.

André Thevet, ([1557] 1978) também faz menção às crenças dos nativos em relação aos pássaros proféticos:

Entre todas as aves desta terra, existe uma que os selvagens não matariam ou mesmo comeriam por nada deste mundo: certo pássaro de piado estridente e melancólico como o das nossas corujas. Dizem as pobres criaturas que esse canto lhes faz recordar os entes queridos que se foram. Este pássaro seria um enviado dos mortos, trazendo boa sorte para os amigos que ainda viviam e azar para seus inimigos (André Thevet, ([1557] 1978): 159).

A presença de pássaros na cosmovisão dos povos nativos trazia, muitas vezes, reverências à certas espécies, como a coruja, tida como ave sagrada e temessem outras que, para eles, estavam falando em nome dos espíritos malignos. Acreditavam que as almas, após a morte, se dirigiam para as montanhas e que os espíritos de seus antepassados voltavam para avisar-lhes e aconselhar-lhes sobre as guerras e como deveriam proceder diante delas. Esses avisos vinham tanto através do canto dos pássaros, como trazidos pelos Caraíbas por meio da cerimônia do maracá.

O tema do pássaro também estava associado aos espíritos malignos ligados a Jurupari e Ainhan. A crença na perseguição feita por tais espíritos, que apareciam em forma de ave "para machucar os homens covardes", era corrente entre os indígenas, segundo Jean de Léry ([1578] 1980).

Jean de Léry ([1578] 1980), ao dissertar sobre a religião dos indígenas, descreve a reação dos Tupinambá em relação aos entes do mal, personificados em formas de aves e quadrúpedes:

Acreditam não só na imortalidade da alma, mas ainda que, depois da morte, as que viveram dentro das normas consideradas certas, que são as de matarem e comerem muitos inimigos, vãos para além das altas montanhas dançar em lindos jardins com as almas de seus avós. Ao contrário as almas dos covardes vão ter com Ainhan, nome do diabo, que as atormenta sem cessar. ...Muitas vezes, como pude presenciar, sentindo-se atormentados, exclamam subitamente enraivecidos: "Defendei-nos de Ainhan que nos espanca". E afirmavam que o viam realmente ou sob a forma de um 
quadrúpede, ou de uma ave ou de qualquer outra estranha figura (Jean de Léry, [1578] 1980: 207).

A figura do pássaro possui um caráter maniqueísta. Aspectos positivos e negativos, com relação ao desencadeamento da existência humana, levam os homens a reverenciar e respeitar os espíritos deificados por eles. A voz dos antepassados ressoa através do seu canto ou o esboço do mal também a personifica. Essa figura fornece ao elemento mítico pássaro, o caráter dual. O que é bom ou ruim para a humanidade é o que é tido como relevante dentro do processo narrativo. Assim, o medo de Ainhan, que os remetiam a uma cena de violência, levava alguns grupos a cultuar e respeitar tais espíritos, mesmo sendo um ente do mal.

Nas pinturas rupestres, o elemento pássaro (Figura 3) está presente em uma grande quantidade de painéis de Tradição Nordeste. Vinculados à figura antropomorfa, aparecem em cenas ritualísticas impregnadas de teor mítico. É a partir da análise da materialidade salientada nas imagens, aliando-as a gestualidade e ao ritmo da narratividade da pintura, que se pode observar qual temática está associada a cada estrutura material e gestual dos componentes. Existem cenas na Tradição Nordeste onde aparecem figuras antropomórficas vinculadas, dentro do contexto narrativo, a outras, cuja identidade zoomórfica é caracterizada.

No conjunto gráfico da Figura 3, observa-se uma associação direta entre o antropomorfo e o ornitomorfo, o que, no contexto dessa associação, o zoomorfo parece adquirir uma conotação mítica. A identidade do homem-pássaro é analisada ao se observar os pés - de aves; o corpo de homem; a cabeça e as asas - de aves. A figura com características humanas e animais foi pintada em um plano mais elevado, em relação ao antropomorfo, sugerindo uma posição de superioridade. A deificação do ser extrapola os limites do humano. O corpo da figura humana aparece de perfil e inclinado para frente em direção ao outro componente. $O$ gesto e a postura se fundem sugerindo uma conotação de reverência e respeito. As mãos direcionadas para a entidade mítica remetem ao sinal de submissão e reconhecimento. 


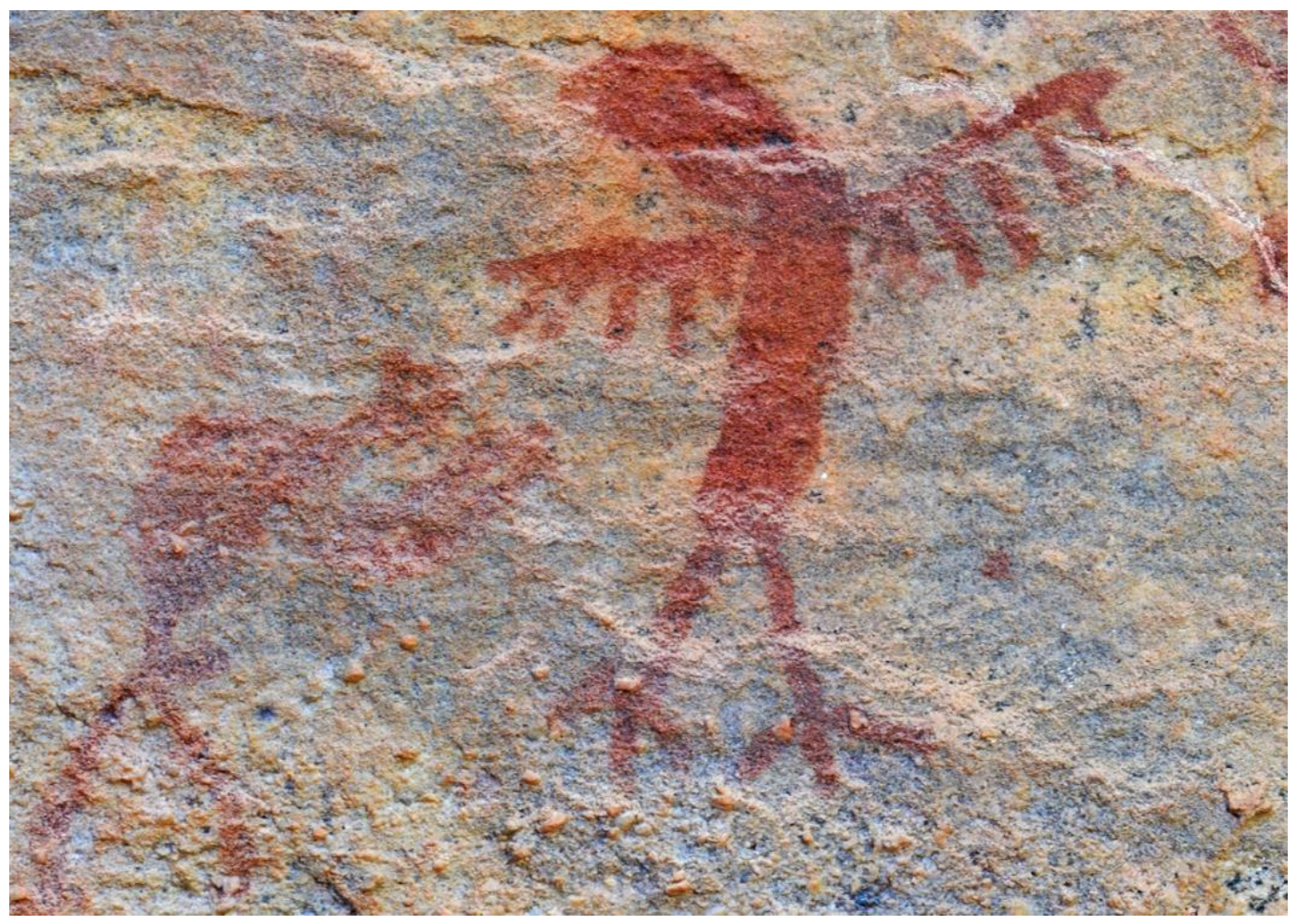

Figura 3: Figura antropomorfa em posição de reverência em relação ao ornitomorfo. Sítio Toca do Caldeirão do Rodrigues I. Parque Nacional Serra da Capivara - PI. Foto: André Pessoa, 2017.

As narrativas referentes à reverência de grupos indígenas aos antepassados que apareciam configurados como pássaros remete à pintura anteriormente descrita. Os gestos e os componentes materiais fornecem elementos que possibilitam a observação de homologias entre as duas narrativas míticas. A presença do pássaro configurando o componente central da assertiva dos cronistas surge na manifestação gráfica também de forma exaltada.

A maneira como os pássaros estão representados nas duas composições míticas exprimem uma similitude na forma de apresentação. Os humanos, subordinados aos antepassados e às figuras deificadas, aparecem de forma a respeitar esses entes, por motivos de adoração, respeito ou medo. A característica comum entre os dois está no gesto e na postura de reverência presente na relação entre o sagrado e o humano. Nas duas formas representativas do mito, o pássaro denota o sagrado, podendo ser ele Jurupari ou um ser mítico que aparece no agenciamento das pinturas no painel como ente superior.

O Maracá e suas funções ritualísticas 
Materialidade dos Mitos Indígenas Narrados nos Séculos XVI e XVII e suas Relações Iconográficas com as Pinturas Rupestres da Tradição Nordeste, Brasil

Outro elemento da cosmogonia indígena é o maracá. Este instrumento composto por uma cabaça e um cabo de madeira podendo estar ornado com pena, foi largamente utilizado pelos nativos em rituais sagrados. Atualmente, grupos indígenas contemporâneos como os Pankararu continuam praticando os gestos instruídos pelos ancestrais, os quais foram conservados como memória da tradição cultural.

O maracá possui duas funções distintas, uma sagrada e outra lúdica (D’Abbeville, [1614] 1975). Este é um instrumento musical que, ao ser balançado, emana um som de chocalho, tendo sido utilizado por grupos indígenas em momentos ritualísticos e de festejos. Nas iconografias quinhentistas pode-se, a partir das imagens de Theodor De Bry ${ }^{3}$ (1592), observar a utilização do maracá em rituais considerados sagrados pelos indígenas (Figura 4).

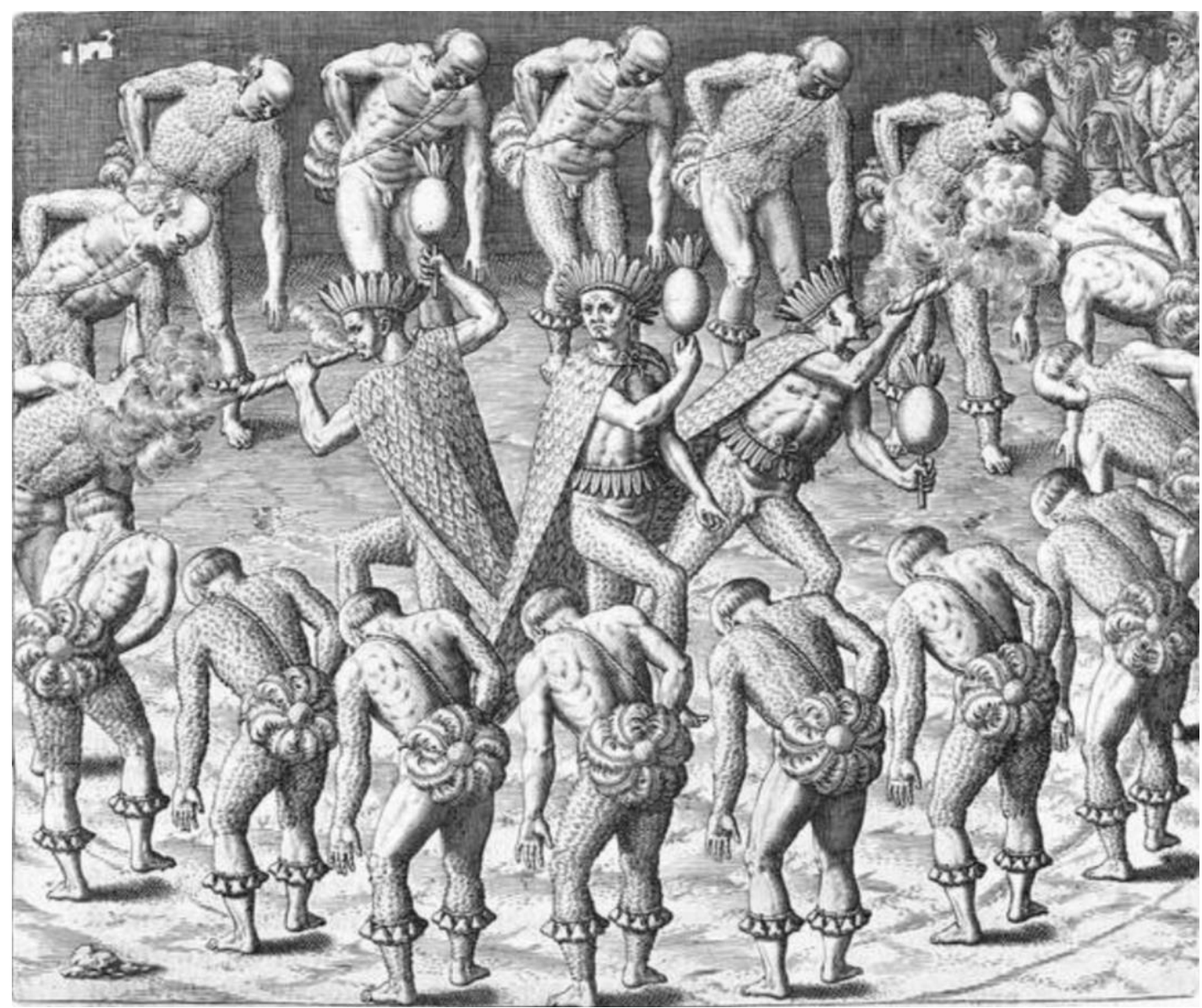

Figura 4: Dança dos Tupinambá com presença de maracás. Em Navigatio in Brasilian Americae 1592, Theodore De Bry apresenta as obras de H. Staden com gravuras a buril calcadas nas xilogravuras originais da obra de H. Staden (ed. 1557). Fonte: Oliveri \& Villa, 2012.

30 trabalho Theodore De Bry (1592) é inspirado no diário de viajantes que descrevem os povos nativos da América e do leste asiático, entre eles configura-se a obra de Hans Staden ([1557] 1988) e Jean De Léry, [1578] 1980. 
Os relatos quinhentistas trazem descrições acerca da dupla funcionalidade do maracá. O Frei Claude D'Abbeville, ao escrever sobre a conduta dos maranhenses, fez uma descrição detalhada do instrumento:

Para observar cadência e marcar o compasso (da dança), usam um instrumento ou chocalho chamado maracá; é feito de um fruto pequeno, alongado e semelhante a um melão de tamanho médio, mas inteiramente liso; esse fruto cresce na região, e dentro dele colocam os índios inúmeros grãozinhos pretos e muito duros. Atravessam-no em seguida com um pedaço de pau para servir de cabo, que cobrem de fio de algodão e enfeitam, nos dias de festa, com lindas plumas de variegadas cores; usam então em suas ligas chocalhos de outros frutos.

Com seus maracás ou chocalhos à guisa de tambores bascos, acompanham suas cantorias. (...) Seus cantos são em louvor de uma árvore, de um pássaro, de um peixe ou de qualquer outro animal ou cousa e não contêm palavras escandalosa (D’Abbeville, [1614] 1975: 237).

Simão de Vasconcelos ([1663] 1977) também descreveu o maracá como um instrumento sagrado, utilizado pelos Caraíbas, como forma de se comunicar com o mundo extrassensível:

Os feiticeiros, agoureiros e curadores, são entre eles os mais estimados; a estes dão toda a veneração; e o que dizem, para com eles é infalível. Os modos de dar seus oráculos, e adivinhar os futuros, são vários, e ridículos: porei um ou dois, por exemplo. Usam alguns de um cabaço a modo de cabeça de homem fingida com cabelos, orelhas narizes, olhos, e boca: estriba esta sobre uma flecha, como sobre pescoço, e quando querem dar seus oráculos, fazem fumo dentro deste cabaço com folhas secas de tabaco queimadas; e do fumo que sai pelos olhos, ouvidos e boca da fingida cabeça, recebem pelos narizes tanto, até que com ele ficam perturbados, e como tomados do vinho, e depois de assim animados, fazem visagens e cerimônias, como se foram endemoniados: dizem aos outros os que lhes vem a boca, ou o que Ihes ministra o diabo; e tudo o que dizem enquanto dura aquele desatino, crêem firmemente, qual se fora entre nós revelação de algum Profeta (Simão de Vasconcelos, [1663] 1977: 121).

Os Caraíbas, nas descrições de Simão de Vasconcelos ([1663] 1977) eram profetas que apareciam nas aldeias e traziam consigo mensagens dos ancestrais. Além disso, prediziam os acontecimentos e tratavam os doentes das aldeias. Além do emprego instrumental, o maracá era utilizado pelos caraíbas para, através dele, escutar a voz dos antepassados. Em tal momento, o instrumento passa a ter uma aplicabilidade mais mitológica. Esses instrumentos musicais deixavam de ser meros chocalhos e passavam a possuir vida. Segundo Jean De Léry ([1578] 1980) os deuses transmutados nos maracás deveriam ser cultuados e alimentados.

Jean De Léry ([1578] 1980) expôs, com minúcia, hábitos e costumes do cotidiano Tupinambá. Com relação aos rituais realizados pelos caraíbas, descreve o respeito que estes impunham e a influência que tinham sobre os demais da tribo: 
Além dessas cerimônias, realizadas de três em três anos ou de quatro em quatro anos, e às vezes mais, ... os Caraíbas vão de aldeia em aldeia e enfeitam com as mais bonitas penas os seus maracás, e fincam-nos em seguida no chão, do lado maior, e ordenam que lhes seja dado comida e bebida. ...E como os habitantes acreditam nisso não deixam de pôr farinha, carne e peixe ao lado dos maracás no chão durante quinze dias a três semanas, após o que lhes atribuem santidade e os trazem sempre nas mãos dizendo que ao soarem os espíritos Ihes vêm falar (Jean De Léry, [1578] 1980: 216).

O valor espiritual e mítico do maracá é também apresentado por André Thevet ([1557] 1978).

Descrevendo a cerimônia praticada para a adoração de Tupã, observa a personificação do maracá pela figura divina:

Cada família possui e guarda uma espécie de fruto do tamanho de um ovo de avestruz, da cor de nossas abóboras, semelhante a uma botelha jurada em ambas as extremidades e atravessada por um bastão de ébano de pé e meio de comprimento. Uma das pontas fica enfiada no chão. A outra é toda enfeitada de belas penas arrancadas de uma ave inteiramente vermelha chamada ará. Os selvagens tratam este objeto com todo o respeito e devoção, como se ele disto fosse merecedor. Acreditam que ele seja seu Tupã, e que seus pajés, ao visitar suas cabanas, podem conversar com eles e escutar as coisas que contam, e que tanto podem referir-se a segredos de seus inimigos quanto a notícias enviadas pelas almas dos amigos falecidos (André Thevet, [1557] 1978; 144).

O símbolo do maracá como instrumento de utilidade ritual também foi retratado nas imagens narrativas das pinturas rupestres de Tradição Nordeste. Em painéis encontrados em sítios arqueológicos, entre eles na Área Arqueológica da Serra da Capivara (Figura 5), é constatada a presença de pinturas agenciadas que denotam cenas marcadas por hermetismos, nas quais é possível ver morfologias similares a de maracás.

A Figura 5 apresenta uma cena de conflito localizada no painel gráfico do sítio Toca do João Arsena, no Parque Nacional Serra da Capivara - PI. A cena apresenta antropomorfos com objetos na mão que, pela morfologia e gestualidade, sugerem se tratar de armas e dois antropomorfos posicionados em oposição ao centro do conflito. Esses antropomorfos com adornos na cabeça seguram dois objetos, um desses objetos tem morfologia linear na base e circular na extremidade, se assemelhando a um maracá. Os gestos, as posturas e os ritmos das imagens antropomorfas dinamizam a pintura e conferem um caráter narrativo. Assim, a cena de antropomorfos não parece seguir um caminho linear, mas ondulatório. 


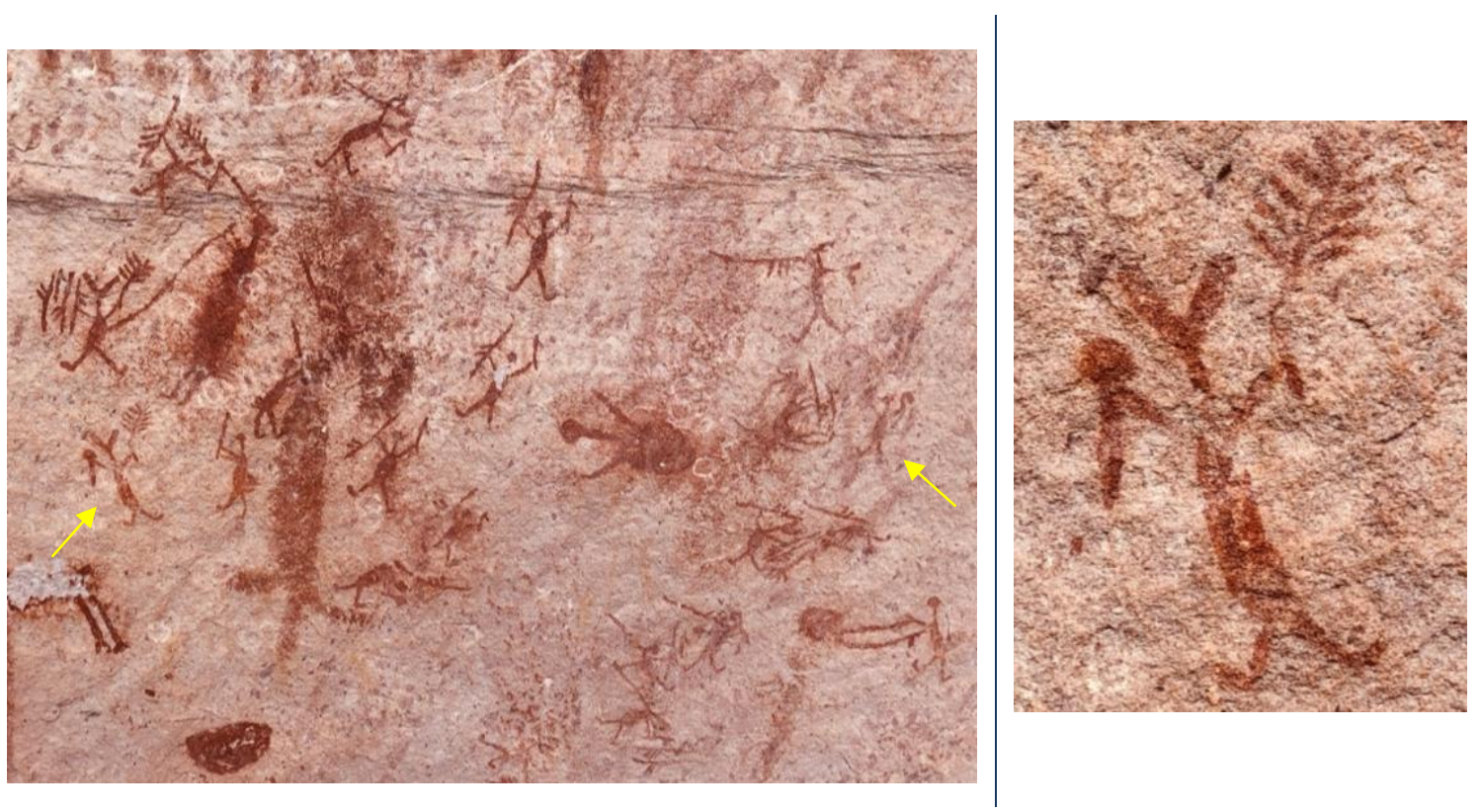

Figura 5: Figuras antropomorfas compondo cena de conflito. Detalhe (setas amarelas) para os antropomorfo portando maracás. Figura ampliada e em destaque. Sítio Toca do João Arsena. Parque Nacional Serra da Capivara - PI. Foto: Daniela Cisneiros, 2019.

A partir das narrativas e iconografias quinhentistas, pode-se observar a existência de componentes homólogos entre estas e as cenas pictóricas de Tradição Nordeste, representadas aqui pelas Áreas Arqueológicas Serra da Capivara - PI. A presença do maracá, inserido em um contexto cerimonial, é observada na encenação. Os adornos e os instrumentos empunhados pelos antropomorfos na pintura rupestre imprimem à cena um sentido figurado, sugerindo ser uma evocação de proteção, poder e força.

\section{Mito da Árvore}

A árvore é um símbolo chave na mitologia dos povos indígenas americanos. Símbolo da vida e da fertilidade, ela está em perpétua evolução direcionada para o céu, evocando relações estabelecidas entre a esfera celeste e a terrena (Clastres, 1990). Na cosmogonia de alguns nativos, esta figura é utilizada como caminho pelo qual os deuses e humanos transgridem as fronteiras dos dois mundos. Claude D'Abbeville ([1614, 1975]), ao descrever as árvores frutíferas da Ilha do Maranhão, aborda a mandioca como planta sagrada, por ser esta a base da alimentação indígena:

Manieup - plante ou petit arbreau - Maniba ou Maniva - A dicção mani, como se usa na composição, é difícil de explicar: pode ser contração de ibáib árvore de finto, por excelência, porque constituía a base da alimentação, como pode ser árvore do céu, segundo a tradição geral e constante na 
América do Sul, da vinda de um ente sobrenatural, de um pai estrangeiro Tumé, Sumé ou Tubé (em quem os catequistas pretenderam reconhecer São Tomé), que veio ensinar às gentes o cultivo das plantas e outras cousas novas. Essas explicações têm o valor de simples hipóteses; o tema permanece indecifrável (D’Abbeville, [1614] 1975: 179).

A mandioca ou árvore do céu constituía a base da alimentação destes povos. Para ser utilizado como alimento, esse vegetal precisa de um tratamento especial, uma vez que sua raiz é venenosa e necessita ser manipulada de forma adequada para o consumo. Cronistas como Claude D’Abbeville ([1614] 1975) e Jean De Léry, ([1578] 1980) relatam que os indígenas explicam que quem os ensinou o cultivo foi um profeta que veio a Terra trazer-lhes tal alimento. Por este motivo, têm a mandioca como mantimento sagrado.

A utilização da figura da árvore transcendendo os limites entre o sagrado e o humano também é observada no mito referente a uma grande tempestade que assolou o mundo em tempos primitivos. Acreditavam que as águas haviam subido de tal forma que muitos morreram afogados, à exceção dos que subiram nas árvores mais altas ou se salvaram em suas embarcações. Alguns cronistas, entre eles, Jean De Léry ([1578] 1980) e Hans Staden ([1557] 1988) narram tais mitos e os rituais vinculados a estes.

Jean De Léry, ao descrever as religiões dos "selvagens da América", relata:

Celebravam ainda em suas canções o fato das águas terem transbordado por tal forma em certa época, que cobriam toda a terra, afogando todos os homens do mundo, à exceção de seus antepassados que se salvaram trepando nas árvores mais altas do país (Jean De Léry, [1578] 1980: 215).

Hans Staden abordando as crenças dos nativos também narra sobre a existência de tal mito:

Narram que houve uma vez uma vastidão de águas na qual todos os seus antepassados morreram afogados. Somente alguns daí escaparam, numa embarcação e outros sobre altas arvores. Penso que deve ter sido o Dilúvio (Hans Staden, [1557] 1988: 174).

A árvore é um componente importante quando se analisa a cosmogonia dos povos, ela aparece denotando longevidade, fertilidade ou como elo entre o céu e a terra. Como afirma André Thevet, ([1557] 1978), com a subida das águas tentavam se salvar em cima das árvores, e, ao subirem, alguns lançavam objetos para ver se as águas baixavam. Estes objetos lançados nas águas serviam como "armas" para afastar os inimigos, mesmo sendo eles espíritos.

Na mitologia Guarani - Paraguai (Clastres, 1990) - as árvores que aparecem para salvar os homens são pindos azuis (palmeiras), árvores sagradas que, além de servir economicamente 
para estes povos, faziam parte da teogonia destes, como as que davam sustentação a Terra ${ }^{4}$. Assim, ao analisar a materialidade dos mitos narrados, nos quais a árvore está inserida, podese observar homologias entre estes e os componentes materiais das pinturas rupestres. A presença de figuras humanas associadas diretamente às árvores está presente nos dois conjuntos narrativos.

Nas pinturas rupestres observa-se a presença do tema árvore em uma grande quantidade de sítios rupestres. Apresentada sob a forma de ramo, galho ou em sua totalidade, a árvore possui um simbolismo de salvação e recriação que extrapola os limites da humanidade. A associação direta de tal elemento com antropomorfos em gesto de adoração, atesta o caráter mítico evocado por ela.

Nas figuras 6 e 7 observa-se a importância do elemento árvore na maneira de retratar dos povos autores. Tais imagens possuem contextos cenográficos complexos, uma vez que os gestos e ritmos das figuras humanas evocam temáticas cerimoniais.

Componentes materiais destas cenas fornecem informações mais complexas sobre os mitos descritos. Nas composições gráficas, a árvore aparece de forma completa e no centro da ação, tendo no seu entorno, figuras humanas elevando os braços em sua direção. O gesto de adoração dos antropomorfos frente à figura fitomórfica transmite o simbolismo mágico representado por ela.

A árvore como figura de adoração e como ente mágico está inserida na cosmogonia de diversos povos. Tanto na mitologia dos grupos indígenas relatados por cronistas e viajantes como nas pinturas rupestres, este tema foi retratado de forma a evocar significados míticos.

As coincidências existentes entre os processos narrativos são persistentes, mas não permite buscar significados para elas, devido ao não conhecimento do contexto vivido pelos povos autores. No entanto, o tema recorrente nas narrativas míticas era possivelmente difuso no momento que foi retratado, bem como estava inserido dentro das preocupações e do cotidiano dos que o representaram graficamente ou ritualmente.

\footnotetext{
${ }^{4}$ Na mitologia Guarani, algumas árvores - árvores sagradas (palmeiras) - haviam emergido durante o dilúvio para salvar os homens que imploravam ao Pai salvação. Estas árvores são as mesmas que acreditavam sustentar a Terra (Clastres, 1990).
} 
Materialidade dos Mitos Indígenas Narrados nos Séculos XVI e XVII e suas Relações Iconográficas com as Pinturas Rupestres da Tradição Nordeste, Brasil

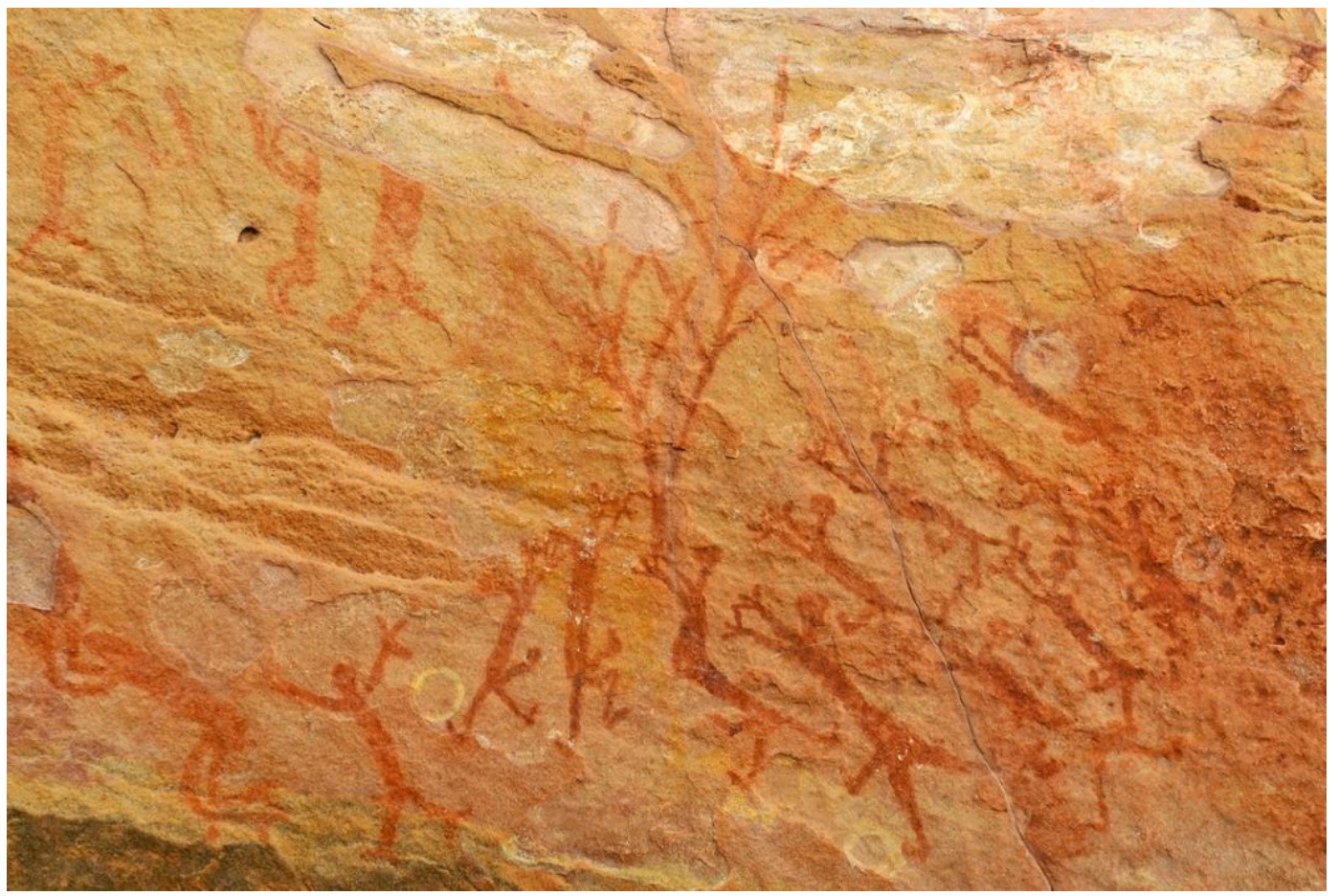

Figura 6: Cena representativa de um ritual em torno da árvore. Sítio Toca da Extrema II. Parque Nacional Serra da Capivara - PI. Fonte: André Pessoa, 2017.

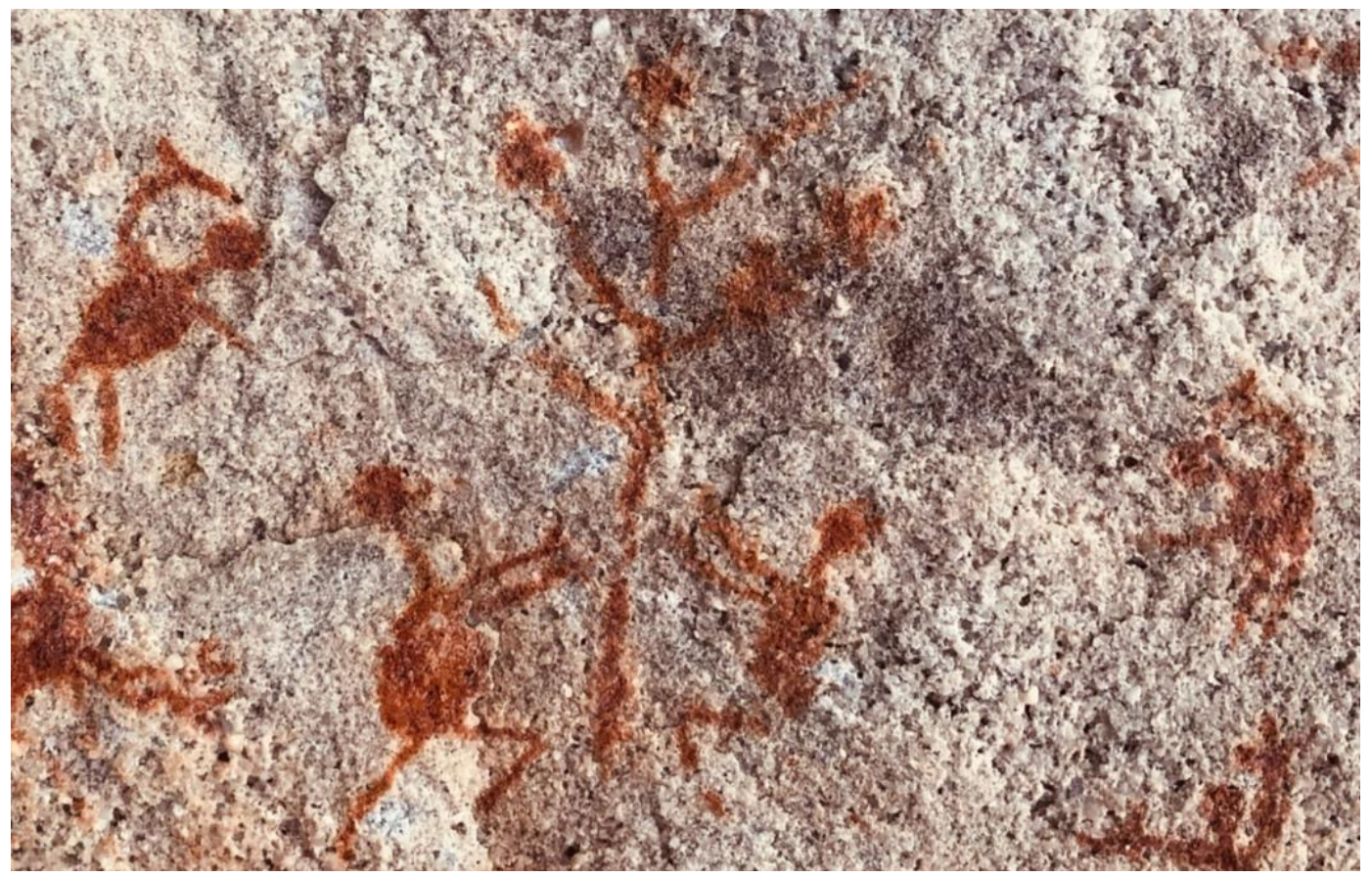

Figura 7: Cena representativa de um ritual em torno da árvore. Sítio Toca da Entrada do Pajau. Parque Nacional Serra da Capivara - PI. Fonte: Daniela Cisneiros, 2019. 


\section{Considerações Finais}

A dimensão material e a gestual, salientadas nas narrativas e painéis rupestres, permitiu constatar a presença de estruturas homólogas entre alguns componentes de tais narrativas imbuídas de aspectos míticos. A mecânica gestual dos componentes e sua agenciação dentro da cena, possibilitaram a observação de posturas e ritmos que suscitam expressões de reverência e respeito.

O tema do homem-pássaro é recorrente em ambas as representações de cunho cerimonial. Dentro das narrativas quinhentistas este tema estava associado diretamente ao mundo sagrado. Os espíritos dos antepassados ou até mesmo Jurupari apareciam, na cosmogonia dos grupos indígenas abordados nos relatos, personificados na figura do pássaro. A esses entes sagrados eram destinados respeito e adoração. Nos painéis rupestres, a figura do pássaro novamente aparece. $\mathrm{O}$ gesto e a postura de submissão do antropomorfo frente à figura ornitomorfa fornece a esta uma conotação de superioridade e deificação. A gestualidade está diretamente associada à dinâmica da ação. $O$ ato de subordinação das figuras humanas em detrimento do ser sagrado é recorrente nos dois processos narrativos.

Em se personificando os deuses ou reverenciando-os a partir do som emitido pelo chocalho, a figura do maracá também possui, dentro do contexto narrativo, o caráter mágico. Os indígenas das narrativas quinhentistas e seiscentistas deificavam tal instrumento, acreditando ser este Tupã. Assim, nos momentos ritualísticos o instrumento maracá era utilizado para evocar os deuses, estando os homens adornados para reverenciar os espíritos dos antepassados.

Nas pinturas rupestres identificaram-se componentes materiais que possibilitaram perceber homologias entre os elementos narrados. As figuras antropomorfas enfileiradas e as que se configuram no plano limítrofe da cena de confronto estão representadas em proporções diferentes, dando a cena um caráter dinâmico. Os gestos de tais componentes permitem inseri-los em um contexto sagrado, segundo narrativas dos cronistas, pois estes possuem adornos e portam maracás, adereços típicos de momentos ritualísticos. A partir da análise cênica das pinturas e das narrativas, observou-se que a figura do maracá é um tema central na composição dos cerimoniais, sendo esse instrumento associado aos adornos e gestos característicos da composição do rito. 
A árvore é um tema clave na composição dos mitos. Nas descrições dos cronistas sobre o universo imaterial indígena, tal temática aparece em diversas manifestações míticas. A árvore aparece como elemento de salvação - no mito do dilúvio - e como elo entre o mundo humano e o celeste. Por esse motivo é reverenciada e compreendida como sagrada. Nas pinturas rupestres, o fitomorfo surge como elemento central e, no seu entorno, aparecem antropomorfos postados em sua direção. Nas duas representações ritualísticas o gesto de reconhecimento e reverência diante da figura da árvore é o ponto central da narrativa.

Para além das analogias, esse trabalho consistiu em apontar a percepção da natureza ontológica dos grafismo e a narratividade expressa no cenário rupestre, que encontra homologias dentro da narratividade e iconografia de cronistas e viajantes dos séculos XVI e XVII, sobre os grupos indígenas contatados.

Não se trata, contudo, de uma analogia direta entre a cosmogonia dos grupos narrados pelos cronistas e os registros rupestres, mas de uma reflexão acerca da arte rupestre como marcadores de memórias e espaços de narratividades com significações e ressignificações.

Como foi ponderado, as fontes de cronistas e viajantes não refletem as realidades indígenas dos séculos XVI e XVII, como também essas narratividades não correspondem diretamente aos contextos arqueológicos representados. Esse trabalho pretendeu lançar uma discussão sobre a dimensão material dos mitos conservados pela tradição oral e confrontá-los com os grafismos reconhecíveis pela sua dinâmica gráfica-narrativa.

Esta análise vem levantar questões acerca das possibilidades de reconhecimento dos elementos materiais. As obras de cronistas e viajantes são aspectos a serem considerados, assim como a narrativa de grupos étnicos atuais e suas elaborações conceituais e ontológicas sobre os grafismos rupestres.

Como argumento final, pode-se sugerir que os elementos gráficos apresentados nessas representações simbólicas vão além das fronteiras dos diferentes significantes gráficos, esses demonstram funções mnemotécnicas e ritualísticas dos grupos autores. 


\section{Referências}

AMARAL, M. P. V. 2008. O Conceito de Alteridade atrelado a representação social do índio no Brasil (Séculos XVI, XVII e XIX). In: Clio - Série Arqueológica, N. 23, Vol. 2. Recife: UFPE.

AMARAL, M. P. V. do. 2014. As pinturas rupestres da tradição agreste em Pernambuco e na Paraíba - Brasil. Tese (Doutorado) Universidade Federal de Pernambuco, Programa de PósGradução em Arqueologia.

ANDRÉ THEVET, [1557] 1978. Singularidades da França Antártica, a que os outros chamam de América. Belo Horizonte: Itatiaia Limitada.

CISNEIROS, D. \& NOGUEIRA, N. 2016. Representações rupestres de adornos de cabeça nos antropomorfos na área arqueológica do Seridó-RN. Revista Clio Arqueológica. Universidade Federal de Pernambuco-UFPE, Recife.

CISNEIROS, D. 2003. Práticas funerárias na Pré-História do Nordeste do Brasil. 2003. Dissertação (Mestrado em História) - Universidade Federal de Pernambuco, Recife.

CISNEIROS, D. 2008. Similaridades e Diferenças nas Pinturas Rupestres Pré-Históricas de Contorno Aberto no Parque Nacional Serra da Capivara - PI. Tese (Doutorado) - Programa de Pós-graduação em Arqueologia, Centro de Filosofia e Ciências Humanas, Universidade Federal de Pernambuco. Recife.

CISNEIROS, D.; NOGUEIRA, N.; SANTOS, C. 2020. A Utilização de Adornos na Pré-História da Área Arqueológica do Seridó - RN. Revista Clio Arqueológica.

CLASTRES, P. 1990. A Fala Sagrada. Mitos e cantos sagrados dos índios Guarani. Campinas, São Paulo: Papirus, 1990.

CLAUDE D'ABBEVILLE, [1614] 1975. História da Missão dos padres capuchinhos na llha do Maranhão e terras circunvizinhas. Belo Horizonte: Itatiaia.

DELUMEAU, J. 2001. História do Medo no Ocidente: 1300-1800, uma cidade sitiada. São Paulo: Companhia das Letras.

ELIADE, M. 2000. Mito e Realidade. São Paulo: Perspectiva.

ELIADE, M. 2001. O Sagrado e o Profano. São Paulo: Martins Fontes.

FERNANDES, F. 1975. Investigação Etnológica no Brasil e outros ensaios. Petrópolis: Ed. Vozes.

GUIDON, N. 1975. Les Peintures Rupestres de Várzea Grande, Piauí, Brésil. Cahiers d’Archéologie d’Ameririque du Sul. Paris, Écoloe de Hautes Étude em Sciences Sociales, n. 3, v.1. 174.

Hans Staden, [1557] 1988. Duas viagens ao Brasil. Belo Horizonte: Itatiaia.

JEAN DE LÉRY. 1980 [1578]. Viagem à terra do Brasil. Belo Horizonte: Itatiaia; São Paulo: Ed. Universidade de São Paulo. 1980.

LEITE, M. N. 2000. A Identidade Humana e o Universo Mítico na Pintura Rupestre. In: Clio. Série Arqueológica $n^{\circ} 14$. Recife, UFPE. 
Materialidade dos Mitos Indígenas Narrados nos Séculos XVI e XVII e suas Relações Iconográficas com as Pinturas Rupestres da Tradição Nordeste, Brasil

LÉVI-STRAUSS, C. 1993. Tristes Trópicos. Lisboa: Edições 70, 1993.

MARTIN, G. 2008. Pré-História do Nordeste do Brasil. 5. ed. Recife: Editora Universitária da UFPE.

OLIVEIRA FILHO, J. P. (org.). 1987. Sociedades Indígenas e Indigenismo no Brasil. Rio de Janeiro: Ed. Marco Zero.

OLIVIERI, A. C. \& VILLA, M.A. 2012. Cronistas dos Descobrimentos. São Paulo: Ática.

PESSIS, A-M. 1987. Contexto e Apresentação Social dos Registros Rupestres Visuais da Antropologia Pré-Histórica. Revista Clio - Arqueológica - UFPE n. 4, v.1, 133-136.

PESSIS, A. M. 1984. Apresentação gráfica e apresentação social na Tradição Nordeste de pinturas rupestres do Brasil. In: CLIO. Série Arqueológica ${ }^{\circ} 05$. Recife: UFPE.

PESSIS, A. M. 1992. Identidade e Classificação dos Registros Gráficos Pré-históricos do Nordeste do Brasil. In: CLIO. Série Arqueológica n ${ }^{8}$. Recife: UFPE.

PESSIS, A. M. 2003. Imagens da Pré-História. Parque Nacional Serra da Capivara. FUMDHAM/PETROBRÁS.

PINTO, E. 1938. Os Indígenas do Nordeste. Coleção Brasiliana, Vol. 112. São Paulo: Companhia Editora Nacional.

RAMINELLI, R. 1994. Imagens da colonização: a representação do índio de Caminha a Vieira. São Paulo: Tese (Doutorado em Antropologia). Programa de Pós-Graduação, USP.

SIMÃO DE VASCONCELOS, [1663] 1977. Crônica da Companhia de Jesus. Vol. 1. Petrópolis: Vozes. 